УДК 001.82:316.75

DOI 10.35423/2078-8142.2019.5-6.04

3. В. Шевченко, кандидат філософських наук, дочент, доиент кафедри філософії та релігієзнавства Черкаського начіонального університету імені Богдана Хмельнииького, м. Черкаси, Україна e-mail: shevchenko.zoe@gmail.com ORCID: https://orcid.org/0000-0001-9980-4372

\title{
СТАНОВЛЕННЯ МЕТОДОЛОГІЧНОГО ПІДХОДУ ДО СОЦІАЛЬНОЇ УДЕНИИЧНОСТІ У ФЕНОМЕНОЛОГІЧНІЙ СОЦІОЛОГІї
}

Статтю присвячено аналізу становлення феноменологічної сочіологї як синтезу класичної феноменологї та елементів методології символічного інтеракиіонізму - на прикладі розгляду проблеми пошуку адекватного методологічного підходу до дослідження сочіальної ідентичності. Зроблено припущення, щзо соціальна ідентичність, відповідно до логіки феноменологічної сочіології Альфреда Шюча, закріплюється при переході від одних «Ми-зв'язків» до інших «Ми-зв'язків» зі збереженням наступності життесвіту. Цю ситуацію Пітер Бергер і Томас Лукман назвуть переходом до інституалізації у процесі кристалізації сочіальних зв'язків, як основним шляхом вторинної соціалізації. Логіка становлення методології феноменологічної сочіології у дослідженні сочіальної ідентичності підводить до необхідності аналізу иієї ідентичності засобами інституйійного аналізу.

Ключові слова: сочіальна ідентичність, сочіальна самість, соиіальні знання, інституалізація, феноменологічна сойіологія, методологічний підхід.

50 (С) Шевченко 3. В., 2019 
Класичним вважають протиставлення соціальної ідентичності як заданої і створеної у феноменології та символічному інтеракціонізмі. У феноменології первинними є чисті феномени, а комунікація між людьми постає як результат застосування цих феноменів до конкретних життєвих ситуацій. Тому і соціальна ідентичність постає, по суті, як задана цими чистими смислами, а створеними виявляються лише іiі варіації. Тоді як у символічному інтеракціонізмі навіть задане є створеним, просто попередніми поколіннями, тут усі змісти свідомості виявляються лише результатом набутого досвіду соціальної взаємодії - поза цією взаємодією смисл зникає. Тим більш цікавим є проект феноменологічної соціології, в якому, як видається, прагнуть поєднати ці два, нібито протилежні, підходи - коли із чистих смислів світ твориться непередбачуваним чином, коли соціальні структури лише у найбільш загальних рисах, як рамочні конструкції, є заданими, а сповнення цих структур конкретними смислами виявляється все ж справою самих учасників комунікації. Таким чином, феноменологічна соціологія розкриває широкі теоретико-методологічні можливості для пояснення феномена множинної соціальної ідентичності.

У феноменології важливими є тексти німецьких філософів Едмунда Гусерля та Мартіна Гайдегера: передусім, «Картезіанські розмисли» першого і «Буття і час» другого. У символічному інтеракціонізму варто звернутися передусім до праць американських теоретиків Чарльза Гортона Кулі і Джорджа Герберта Міда «Людська природа і соціальний лад» першого та «Дух, самість i суспільство» другого. А в традиції феноменологічної соціології варто зупинитися та «Структурах життєсвіту» Альфреда Шюца i «Соціальному конструюванні реальності» Пітера Бергера і Томаса Лукмана, які і за своєю біографією, і за філософською позицією поєднують німецьку (передусім, феноменологічну) філософію i американську школу філософування.

Спробуємо простежити, якою мірою феноменологія, символічний інтеракціонізм і феноменологічна соціологія можуть розкрити тему множинної соціальної ідентичності.

Прийнято вважати, що саме Мід є автором концепції творення власної соціальної ідентичності на основі запозиченого досвіду, який людина отримує у безпосередній взаємодії з іншими людьми. 
Однак, ще раніше, інший американський дослідник, Чарльз Кулі формулює концепцію «дзеркальної самості» [4], в якій розкриває важливий механізм утворення соціальної ідентичності, який Мід далі удосконалює. «Дзеркальна самість» $є$ умінням людини адаптуватися до реакції інших людей на ії поведінку: інші постають як своєрідне дзеркало, в якому ми вчимося впізнавати себе - не такими, як нам видається у наших фантазіях і бажаннях, а такими, як ми зуміли показати себе фактично іншим: «Я не $\epsilon$ таким, яким я про себе думаю. Я не є таким, яким ви про мене думаєте. Я $є$ таким, яким я думаю, ви думаєте, я є» (I am not what I think I am. I am not what you think I am. I am what I think you think I am). Далі Кулі наводить приклад цієї логіки: «... ми соромимося здаватися нещирими в присутності прямодушної людини, боягузами - в присутності хороброго, грубими - в очах людини з тонкими манерами тощо. Ми завжди уявляємо уявлення інших про нас, поділяємо судження іншої свідомості. Перед одним людина стане хизуватись своїм вчинком, про який ій буде соромно розповісти іншому» [3, с. 317]. Кулі застосовував метод дослідження, який він назвав «симпатичним самоспостереженням» (sympathetic introspection): дослідник має уявити себе у ролі іншої людини, буквально відчути себе нею. Така метода не є чимось надто складним, адже, як бачимо 3 прикладів, які наводить Кулі, всі люди схильні «заражатися» соціальним середовищем, переймати його характеристики і непомітно зливатися 3 ним - чим триваліше в ньому знаходяться. Тим самим Кулі відкриває можливість припустити: у скількох соціальних середовищах перебуває почергово людина, такі свої «віддзеркалення» вона може отримати. Це можуть бути не лише окремі соціальні ролі, хоча такий спосіб структурування соціальної ідентичності є найбільш типовим, а й цілісні і відносно самодостатні соціальні світи, в кожному з яких відбувається впізнавання себе зовсім іншим.

Уже наприкінці XIX ст. у романі шотландського письменника Роберта Льюїса Стівенсона «Дивна історія доктора Джекіла i містера Хайда» викладена ситуація, коли людина живе подвійним життям, і не підозрює про це [8]. Цей випадок став хрестоматійним прикладом психічного розладу - а скільки в реальності трапляється історій, коли люди свідомо живуть подвійним життям: шпигуни, 52

Institute of Philosophy of H. S. Skovoroda of NAS of Ukraine 
революціонери-підпільники, таємні коханці, скільки відомо випадків подвійної бухгалтерії, подвійних стандартів, подвійної моралі! Однак, Кулі так далеко ще не заходить, хоча вже він фіксує розбіжності між внутрішнім баченням людиною себе і тим образом себе, який знаходить у свідченнях інших людей. У Стівенсона роздвоєння особистості $є$ результатом свідомого експерименту «безумного вченого» над самим собою. Психіатрія розглядає такі роздвоєння як правило, як несподівані зміни у структурі особистості. Однак, визрівають вони все ж у будь-якому разі тривалий час - людина не може перейняти на себе повністю чи частково особистість, яка для неї є зовсім чужою, невідомою. Скоріше відбувається розщеплення набутого соціального досвіду на відносно автономні частини - особливо у випадках наростання внутрішніх гострих суперечностей всередині цього досвіду.

Мід додає до розуміння соціальної самості аналіз внутрішньої динаміки іï становлення. Це дає можливість відстежувати ті зміни, які раніше здавалися раптовими і безпідставними. 3'ясувалося, що сама людина плекає в собі свою соціальну самість, а інші лише підштовхують іiі у різних напрямах: якщо ці зовнішні спрямовування $\epsilon$ когерентними, тоді і соціальна самість людини має усі шанси залишитися цілісною, якщо ж соціальне середовище людини доволі гетерогенне, тоді і виникають ситуації, коли людина отримує можливість дуже по-різному визначати свою соціальну самість: «Голосовий жест стає значимим символом (неважливий, якщо є просто елементом емоційного боку досвіду), коли здобуває такий же вплив на індивіда, який його продукує, як і той, що він виявляє на індивіда, котрому адресується, чи того, хто явно реагує на нього, і таким чином він передбачає відношення до самості продукуючого його індивіда. Значимий жест взагалі, і голосовий жест зокрема, означає той чи інший об'єкт всередині сфери соціальної поведінки, об'єкт спільного інтересу для всіх індивідів, залучених до даної соціальної дії, таким чином спрямованої до даного об'єкта чи на нього. Функція цього жесту в тому, щоб зробити можливим взаємоузгодження серед індивідів, залучених до будь-якої даної соціальної дії стосовно об'єкта чи об'єктів, 3 котрими ця дія пов'язується; і значимий жест чи значимий символ надає значно більші можливості для такого взаємного налаштування і перелаш- 
тування, ніж просто не значимий жест, тому що він викликає в індивіді, котрий його продукує, ту ж налаштованість до нього (чи до його значення), яке він викликає у інших індивідів, які разом з першим індивідом беруть участь в даній соціальній дії, і таким чином робить цього індивіда свідомим їхньої налаштованості до даного жесту (як компонента його поведінки) і дає названому індивіду можливість пристосувати свою подальшу поведінку до їхніх у світлі цієї налаштованості»»» [6, с. 41]. Однак, за Мідом, здається, це все ж завжди буде одна соціальна самість - людина може змінювати іiі, і доволі радикально, однак дві соціальні самості в однієї людини все ж уявити в межах теорії Міда неможливо. Однак, цілком можливо використати цю теорію для пояснення, як ці різні соціальні самості можуть з'являтися.

Загалом, сам пафос символічного інтеракціонізму, здається, саме і полягає у тому, щоб пояснити, як 3 множини соціальних впливів і виконання множини соціальних ролей особистість формує власну соціальну самість як щось єдине, як певний стрижень, довкола якого і обертаються усі ці соціальні взаємодії: саме полюс «I», тобто «я» людини як суб'єкта діяльності є джерелом спонтанності, активності, творчості. Саме цей полюс узгоджує різнорідні джерела смислу, надаючи їм єдину, послідовну, наскрізну інтерпретацію. У цьому взагалі полягає можливість утворення соціальної самості: без такої єдності смисли не просто розпадалися би на множину різнорідних даних, вони не могли б навіть виникати адже, за Мідом та іншими символічними інтеракціоністами, смисли вперше виникають у соціальній взаємодії як інтерпретація жестів. Отже, немає жестів - немає смислів, тож немає й з чого творити конкретну соціальну самість.

Пізніше у гендерних теоріях часто спостерігаємо аналогічну логіку: не біологічна стать жорстко визначає гендер, а саме те, як людина використовує свої біологічні дані, визначає гендер, тобто гендер має принципово функціональну природу, на противагу субстанційності біологічної статі [12]. Гендер є сконструйованою ідентичністю, так само, як і соціальна самість: він не $є$ повністю вигаданим, однак може суттєво переформатовувати свої наперед задані біологічні передумови. I переформатовує їх саме завдяки соціально-культурним засобам, а тому гендер слід розглядати як важливу 54

Institute of Philosophy of H. S. Skovoroda of NAS of Ukraine 
складову соціальної самості особистості. Людина також не може бути водночас носієм двох гендерів, як не може бути носієм двох самостей одномоментно. Утім, усередині соціальної самості, як і всередині гендеру, як нам видається, цілком можливі доволі розмаїті форми структурації, а їхнє виникнення також може бути успішно пояснене тими механізмами, які аналізував Мід для формулювання концепції соціальної самості.

Утім, наявність одних і тих самих, або дуже подібних змістових характеристик соціального досвіду може мати не лише еволюційне пояснення, до якого, вочевидь, схиляє теорія Міда, а й версію пояснення, яка базується на конститутивній спільності цих характеристик, яка має трансцендентальні засади. У будь-якому разі, саме до цього веде класична феноменологія Гусерля та його ортодоксальних послідовників. Символічний інтеракціонізм припускає, що навіть найскладніші змісти нашого досвіду мають своє походження від найпростіших змістів - але у дуже віддаленому моменті історичного часу: так ми переймаємо вже доволі складні конструкції соціального досвіду від наших попередників, але вони переймали дещо простіші - від своїх, а ті ще трошки простіші - ще від більш віддалених попередників, і так у історичній регресії можна дійти (гіпотетично) до елементарних соціальних смислів, які були у прадавні часи вперше передані нашими першопредками за допомогою елементарних соціальних жестів. Можливо, це була протомова, а можливо іiі жестовий аналог. У будь-якому разі, соціальний досвід дуже повільно, але неухильно ускладнювався в процесі еволюції людства - до того ж зростав не лише кількісно, а й якісно. Якщо ж звернути увагу на позицію феноменологів, то вони наполягають, що найважливіші смисли є не лише найпростішими, «чистими» від емпіричних нашарувань, а й незмішаними між собою (як ідеї Платона). Такі прості і чисті смисли уможливлюють функціонування людської свідомості завжди - i нині, і у далекому минулому, і у далекому майбутньому: вони не еволюціонують, адже еволюціонувати можуть лише їхні емпіричні втілення. Утім, щоб уникнути метафізики, феноменологи також визнають світ інтерсуб'єктивності як носія цих смислів, хоча все ж і не як їхнє джерело. 
У «Картезіанських розмислах» Гусерль ставить питання розрізнення свого і чужого у сфері змістів свідомості: адже якщо речі матеріального світу ми відносно легко можемо розділити на власні, наші, і чужі, які нам не належать, або належать лише частково, як взяті у користування, то у сфері свідомості провести такі кордони набагато складніше, майже неможливо. Як смисли, які в основі своїй є трансцендентальними, можуть ставати власними або бути чужими, має дослідити генетична феноменологія, до якої звертається Гусерль. Однак, генезис у феноменології і еволюція у природі - зовсім різні речі: у природі еволюціонують матеріальні об'єкти, а у свідомості, яку досліджує феноменологія, відстежується генезис складних переживань із переживань простих - тобто в межах самої свідомості. Більше того, зв'язки з матеріальним світом тут також, по суті, не аналізуються, адже замість них феноменологи аналізують зв'язок актів свідомості і предметністю, яку усвідомлюють: замість класичної взаємодії суб'єкта (людини) і об'єктів (матеріального світу) феноменологи досліджують перехід від активного синтезу до пасивного синтезу всередині самої свідомості. Вийти з цього соліпсизму свідомості Гусерль намагається за допомогою концепту Іншого як іншого еgo, який Гусерль розгортає у п’ятій медитації, коли ставить питання про досвід Іншого: «Маємо все ж зробити для себе приступною ту експліцитну і імпліцитну інтенційність, у якій на грунті нашого трансцендентального Ego заявляє про себе і проголошує себе alter ego; як, у яких інтенційностях, у яких синтезах, у яких мотиваціях смисл іншого Еgо утворюється в мені і під назвою узгодженого досвіду чужого засвідчує себе як суще і навіть як те, що саме себе підтверджує специфічним чином» [2, с. 118]. Як бачимо, реальна взаємодія з іншим підміняється тут досвідом чужого, замість реального іншого Ego аналізується alter ego всередині самого Ego, який зовсім не обов'язково може виявитися адекватним, але має бути безумовно внутрішньо когерентним з усім іншим досвідом Еgo. Можливо, саме тому Гусерль приходить до ідеї феноменологічної монадності, за якої різні Ego співіснують як замкнені в собі, а узгоджена взаємодія між ними пояснюється не реальною соціальною взаємодією (як у символічному інтеракціонізмі), а спільною природою цих Ego, яка ство- 
рює ситуацію, аналогічну наперед встановленій гармонії у монадології Вільгельма Ляйбніца.

У цьому контексті дещо «підвішений» у повітрі статус набувають розмисли Гусерля про «духовну Європу» в його відомій праці «Криза європейського людства і філософія» [3], адже якщо немає чіткого зв'язку навіть 3 конкретним Іншим, тоді як можна говорити про спільність усієї Свропи? Достеменно - лише як про уявну, таку, що є досвідом самого Гусерля, який він засвідчує своєю працею. До речі, текст цих доповідей Гусерль читав у 1935 році у Відні, а не в Німеччині - вочевидь тому, що фактично Європа навіть для Гусерля вже втратила свою єдність, навіть якщо іiі і мала до того: нацистська Німеччина стала для нього духовно чужою, як і він для неї.

Тому особливу увагу привертає версія феноменології Мартина Гайдегера, яку він виклав у праці «Буття і час» [9], в якій німецький мислитель аналізує усе соціальне буття лише як суще, лише як можливість виходу до справжнього буття Dasein як осьбуття, яке відкривається особистості, а не масам, заглибленому у філософські питання і ангажованому екзистенціалами мисленню, а не чуткам, теревеням та іншим проявам анонімної соціальності das man, тобто людей взагалі: «Люди $є$ екзістенціалом і належать як вихідний феномен до позитивного облаштування ось-буття. Вони мають самі знову ж різні можливості своєї ось-буття-розмірної конкретизації. Наполегливість і вираженість їх панування можуть історично змінюватися. Самість повсякденного ось-буття $є$ людино-самість, яку ми відрізняємо від власної, тобто власне взятої на себе самості. Як людино-самість ось-буття завжди розсіяне в людях і має себе спершу знайти» [9, с. 152-153]. Таким чином, Гайдегер бачить соціальну взаємодію доволі інструментально - це лише неминучий шлях до себе, до своєї самості. Німецький мислитель зберігає центрованість феноменології на самості - нехай вона вже не $\epsilon$ Ego, а є ось-буття, але у будь-якому разі інші люди виявляються завжди чимось додатковим до цього ось-буття, цієї самості.

Випадок Гайдегера чітко артикульовано і експліковано засвідчує, що для класичної феноменології самість по суті ніколи не $є$ соціальною самістю. Для феноменологів соціальність взагалі є лише одним з феноменів поруч з іншими - наприклад, улюбленими 
для феноменологів кольорами або емоційними переживаннями, найбільш глибокі з яких Гайдегер іменує екзистенціалами. У цьому полягає не лише обмежене розуміння соціальної ідентичності як чогось поверхневого для цієї індивідуальної самості, чогось не самодостатнього, а й взагалі радикальна онтологічна і аксіологічна недооцінка суспільства феноменологами. Протиставлення символічного інтеракціонізму і класичної феноменології постає відповідно як протиставлення акцентування на соціальному і індивідуальному началах при визначенні ідентичності. Якщо символічні інтеракціоністи надають завеликого значення соціальній взаємодії у формуванні соціальної ідентичності, то класичні феноменологи явно занижують значущість соціальної взаємодії у формуванні соціальної ідентичності. Утім, у феноменології теж $є$ важливий потенціал, який згодом розкриє соціальна феноменологія: соціальна взаємодія має свою структуру, і аналіз структур усвідомлення соціальної реальності у соціально орієнтованій феноменології дає можливість зафіксувати складні структури соціальної взаємодії як структури смислові.

Крім того, базова методологічна дилема індивідуального i соціального при визначенні сутності соціальної ідентичності має ще один суттєвий аспект. Ця дилема, як у символічних інтеракціоністів, так і у класичних феноменологів, виникає при аналізі свідомості і в межах філософії свідомості: і ідентичність, і самість, і соціальна ідентичність, і соціальна самість $є$ конструктами свідомостi.

Соціально орієнтована феноменологія має кілька версій свого втілення, головною серед яких $є$ феноменологічна соціологія. Не можна також відкидати значущості феноменології тілесності, передусім у філософії Моріса Мерло-Понті та Емануеля Левінаса, та особливого перформативного підходу до соціальності у так званій постфеноменології Жан-Люка Маріона, Анрі Мальдіне та Марка Рішіра [7]. Окрему важливу лінію у соціальній феноменології являє собою аналіз соціального феномена Чужого, здійснений передусім Альфредом Шюцем і Бернгардом Вальденфельсом, який ми раніше вже аналізували [10]. Однак, вирішальний внесок у розгорнуте феноменологічне розуміння соціальної ідентичності здійсни- 
ли саме Альфред Шюц, Пітер Бергер та Томас Лукман, яких об’єднував проект так званої феноменологічної соціології.

У своїй праці «Соціальне конструювання реальності» Бергер і Лукман здійснюють відвертий синтез феноменології і символічного інтеракціонізму: «Ідентичність, безумовно, є ключовим елементом суб'єктивної реальності. Як будь-яка суб'єктивна реальність, вона знаходиться в діалектичному взаємозв'язку із суспільством. Ідентичність формується соціальними процесами. Після того, як одного разу викристалізувалася, вона підтримується, видозмінюється або навіть переформовується соціальними відносинами. Соціальні процеси, пов'язані з формуванням і підтриманням ідентичності, детермінує соціальна структура. I навпаки, ідентичності, створені завдяки взаємодії організму, індивідуальної свідомості і соціальної структури, реагують на дану соціальну структуру, підтримуючи, модифікуючи або навіть переформовуючи іiі» [1, с. 278]. Як бачимо, феноменологічна соціологія додає до опозиції «індивід-люди» ще й опозицію «біологічне-соціальне».

Для феноменологічної соціології соціалізація вже не є якоюсь сумнівною реальністю, яка нерідко обертається неминучим злом або химерою, як це траплялося у Гусерля і Гайдегера, але магістральним напрямом становлення будь-якої ідентичності. Вони відкидають его-центроване поняття самості і зосереджуються на понятті ідентичності. I тоді з'ясовується, що іншого шляху для людини, як перейти із суто біологічного статусу у власне людський, крім соціальності, не існує: «У повністю соціалізованого індивіда наявний безперервний внутрішній діалектичний зв'язок ідентичності з їі біологічним субстратом. Індивід продовжує сприймати себе як організм, що є відособленим, а іноді і такий, що протистоїть соціально виведеним об'єктиваціям себе самого. Часто цю діалектику розуміють як боротьбу «вищого» і «нижчого» Я, які прирівнюють відповідно до його соціальної ідентичності та досуспільної, можливо анти-суспільної, тваринності. «Вище» Я повинне постійно стверджувати себе в боротьбі з «нижчим», іноді настає час критичної перевірки його сил» [1, с. 278]. При переході до поняття соціальної ідентичності як одного з базових феноменологічні соціологи апелюють до марксистського розуміння діалектики соціальних процесів, однак суттєво переосмислюють його на 
манер соціології знання, коли вже не матеріальне виробництво, а виробництво повсякденного знання стає базовим, визначальним соціальним процесом. Таким чином, Бергер і Лукман досягають успішного розв'язання дилеми індивідуального і соціального завдяки відходу від філософії свідомості і зверненню до теми соціального знання.

Утім, ще раніше Альфред Шюц наголошував на важливості переходу від аналізу соціальних знань до аналізу соціальних діянь - від теорії до практики. Його погляди останніх років систематизував Томас Лукман і вже по смерті Шюца видав у співавторстві 3 ним програмну роботу «Структури життєсвіту». Дилему «індивідлюди» вони долають за допомогою не діалектики, а праксеології: «С люди, які можуть щось вчинити або утриматися від цього. I люди є людьми - та взагалі вперше стають людьми - лише серед таких, як вони. Іншими словами, людина, яка діє, існує в суспільстві» [11, с. 433]. Шюц і Лукман наголошують, що діяти людина може лише разом з іншими людьми, до того ж обов'язково у режимі відтворення їхнього спільного життєсвіту як світу їхньої повсякденності: «Це поняття походить із царини, в якій завжди діє найважливіше з пов'язаних зі суспільністю життєсвіту припущень, а саме припущення взаємності перспектив (можливості обміну точками зору та конгруентності систем релевантностей). Якщо ми не хочемо повністю спростити смисл поняття дії, ми не можемо застосовувати його навіть до всіх людських одиничних досвідів, а тим паче до всіх як завгодно організованих подій у світі. Якщо його переносять на щось позалюдське, то це завжди відбувається у настанові, яка звільнена від безпосередніх вимог повсякденності. Разом із тим не можна заперечувати, що позаповсякденні теорії впливають на здоровий людський глузд. Але ще до будь-якої теорії у природній настанові повсякденного життя діють лише люди» [11, с. 433].

Для Шюца і Лукмана соціальна ідентичність - це не абстрактна соціальна єдність, а спільна соціальна релевантність, яка утворюється на основі взаємного визнання зустрічних соціальних стратегій конкретних людей. Сам термін «соціальна ідентичність» вони в цій роботі не вживають, однак надають багатий матеріал для раціональної реконструкції соціальної ідентичності на основі діяння. 60

Institute of Philosophy of H. S. Skovoroda of NAS of Ukraine 
Важливу роль у формулюванні орієнтованих на іншого стратегій діяння та досягненні порозуміння відіграє мова: «У подальших домовних, а потім також мовних процесах інтерсуб'єктивного віддзеркалювання у конкретних Ми-зв'язках не лише розвивається, посилюється та змінюється персональна ідентичність, а й водночас формується здатність до складних діянь. Можна також наголосити, що домовне, взаємно комунікативне діяння у безпосередності Мизв'язків утворює неодмінну передумову здобуття мови й опосередкованого цією мовою релятивно-природного світоспоглядання» [11, с. 446]. Власне соціальна ідентичність, вочевидь, виникає, коли індивіди переходять від взаємно-безпосереднього діяння до взаємно-опосередкованого діяння [11, с. 458], тоді як суспільно орієнтоване діяння стає вже надто абстрактним для встановлення соціальної ідентичності. Можна припустити, що соціальна ідентичність, відповідно до логіки феноменологічної соціології, закріплюється при переході від одних «Ми-зв'язків» до інших «Ми-зв'язків» зі збереженням наступності життєсвіту. Цю ситуацію згодом, у вже згаданій нами роботі Бергер і Лукман назвуть переходом до інституалізації у процесі кристалізації соціальних зв'язків, як основним шляхом вторинної соціалізації: «... соціальна взаємодія між вчителями та учнями може бути формалізована. Вчителям не треба бути значущими іншими в будь-якому сенсі слова. Вони - інституційні функціонери, формальним призначенням яких $є$ передавання соціального знання. При вторинній соціалізації ролі характеризуються високим ступенем анонімності, тобто вони досить віддалені від їх індивідуальних виконавців» [1, с. 230].

Таким чином слід визнати, що логіка становлення методології феноменологічної соціології у дослідженні соціальної ідентичності підводить до необхідності аналізу цієї ідентичності засобами інституційного аналізу. Утім, на відміну від класичного інституціоналізму, такий інституціоналізм має розглядати соціальні інститути не як «поцейбічні трансценденції», автономну щодо індивідів реальність, але як спосіб їх свідомого і активного, творчого облаштування власного життєсвіту. До такого розуміння інституціоналізму наближається неоінституціоналізм, однак це вже має бути предметом окремого дослідження. 


\section{ЛITЕРАТУРА}

1. Бергер П., Лукман Т. Социальное конструирование реальности: Трактат по социологии знания / пер. с англ., вступление Е. Д. Руткевич. М. : Медиум, 1995. 324 с.

2. Гуссерль Э. Картезианские медитации / пер. с нем. В. И. Молчанова. М. : Академический проект, 2010. 229 с.

3. Гуссерль Е. Криза європейського людства і філософія / пер. 3 нім. Є. Причепій. Сучасна зарубіжна філософія. Течї̈ і напрями. Хрестоматія / упорядники В. В. Лях, В. С. Пазенок. К.: Ваклер, 1996. С. 62-94.

4. Кули Ч. Социальная самость / пер. с англ.. Американская социологическая мысль: Тексты / ред. В. И. Добренкова. М.: Изд-во МГУ, 1994. С. 316-330.

5. Кули Ч. Человеческая природа и социальный порядок / пер. с англ. М. : Идея-Пресс, 2000. 309 с.

6. Мід Дж. Г. Дух, самість і суспільство. 3 точки зору соціального біхевіориста / пер. 3 англ. Т. Корпало. К. : Український центр духовної культури, 2000. 374 с.

7. (Пост)феноменология: новая феноменология во Франции и за ее пределами / Сост. С. А. Шолохова, А. В. Ямпольская. М. : Академический проект, 2014. $288 \mathrm{c.}$

8. Стивенсон Р. Л. Странная история доктора Джекила и мистера Хайда / пер. с англ.. М. : Восточная книга, 2013. 368 с.

9. Хайдеггер М. Бытие и время / пер. с нем. В. В. Бибихина. Х. : Фолио, 2003. 503 с.

10. Шевченко 3. В. Чужий як чинник творення соціальної ідентичності особистості (традиція феноменологічної соціології). Мультиверсум. Філософський альманах. 2018. Вип. 3-4 (165-166). С. 19-30.

11. Шюц А., Лукман Т. Структури життєсвіту / пер. 3 нім. Вахтанга Кебуладзе. К. : Український Центр духовної культури, 2004. 560 с.

12. Boichenko M., Shevchenko Z., Pituley V. The role of biological and social factors in determining gender identity In: Anthropological measurements of philosophical research. 2019. № 15. P. 11-21.

\section{REFERENCES}

Berger, P., Lukman, T. (1995). Social construction of reality: A treatise on the sociology of knowledge. Moscow: Medium. [In Russian].

Husserl, E. (2010). Cartesian meditations. Moscow: Academic project. [In Russian]. 
Husserl, E. (1996). The Crisis of European Humanity and Philosophy. In: Modern foreign philosophy. Currents and directions. Reader. 62-94. [In Russian].

Cooley, Ch. H. (1996). Social self. In: American Sociological Thought. V. I. Dobrenkova. (Ed.). Moscow: Moscow State University Publishing House. Pp. 316-330. [In Russian].

Cooley, Ch. H. (2000). Human nature and social order. Moscow: Idea-Press. [In Russian].

Mead, G. H. (2000). Mind, Self and Society. From the point of view of the social behaviorist. Kyiv: Ukrainian Center for Spiritual Culture. [In Ukrainian].

(Post) Phenomenology: New Phenomenology in France and Beyond. (2014). S. A. Sholokhov, A. V. Yampolskaya (Comp.). Moscow: Academic project. [In Russian].

Stevenson, R. L. (2014) Strange story of Dr. Jekyll and Mr. Hyde. Moscow: The Eastern Book. [In Russian].

Heidegger, M. (2003). Being and time. Harkiv: Folio. [In Russian].

Shevchenko, Z. V. (2018). Alien as a Factor of Creating Social Identity of Personality (Tradition of Phenomenological Sociology). Multyversum. Filosofskyy almanakh. (Multiversum. Philosophical almanac), Vol. 3-4 (165-166). [In Ukrainian].

Schutz A., Lukman T. (2004). Structures of lifeworld. Kyiv: Ukrainian Center for Spiritual Culture. [In Ukrainian].

Boichenko, M., Shevchenko, Z. \& Pituley, V. (2019). The role of biological and social factors in determining gender identity. Anthropological measurements of philosophical research, Vol. 15, 11-21. [In English]

\section{Zoya Shevchenko}

Candidate of Philosophical Sciences (Ph.D.), Associate Professor, Associate Professor, Department of Philosophy and Religious Studies

Cherkasy National University named after Bogdan Khmelnitsky; Cherkasy, Ukraine; e-mail: shevchenko.zoe@gmail.com; ORCID: https://orcid.org/00000001-9980-4372 


\section{Formation of a methodological approach to social identity in phenomenolog- ical sociology}

\section{Abstracts}

The article is devoted to the analysis of the formation of phenomenological sociology as a synthesis of classical phenomenology and elements of the methodology of symbolic interactionism - by examining the problem of finding an adequate methodological approach to the study of social identity. Mead adds to the understanding of social self an analysis of the internal dynamics of its formation. This makes it possible to track changes that previously seemed sudden and unwarranted. The person himself cherishes his social self, while others only push him in different directions. The task of symbolic interactionism is to explain how, from the multiplicity of social influences and the fulfillment of the multiple social roles, the individual forms his own social self as something, as a core, around which all these social interactions revolve. Symbolic interactionism is based on the evolutionist assumption that even the most complex meanings of our experience originate from the simplest meanings - but at a very distant moment in historical time. The juxtaposition of symbolic interactionism and classical phenomenology appears, respectively, as a juxtaposition of the emphasis on social and individual principles in defining identity. If symbolic interactionists attach great importance to social interaction in the formation of social identity, then classical phenomenologists clearly underestimate the importance of social interaction in the formation of social identity. The basic methodological dilemma of the individual and the social in determining the essence of social identity, both in symbolic interactionists and in classical phenomenologists, arises in the analysis of consciousness and within the philosophy of consciousness: and identity, and self, and social identity, and consciousness, and social identity, and social identity. In the transition to the concept of social identity as one of the basic phenomenological sociologists appeal to the Marxist understanding of the dialectics of social processes, but significantly rethink it in the manner of sociology of knowledge, when it is no longer material production, and the production of everyday knowledge becomes a basic, determining social. For Alfred Schütz and Thomas Luckman, social identity is not an abstract social unity, but a shared social relevance, which is formed on the basis of mutual recognition of counter-social strategies of specific people. The term "social identity" is hardly used, but it provides rich material for the rational reconstruction of social identity through action. The assumption is made that social identity in accordance with the logic of the phenomenological sociology of Schütz is fixed during the transition from one "We-connections" to other "We-connections" while maintaining the continuity 
of the life world. Berger and Thomas Luckman will call this situation the transition to institutionalization in the process of crystallization of social ties, as the main way of secondary socialization. The logic of the formation of the methodology of phenomenological sociology in the study of social identity leads to the need to analyze this identity by means of institutional analysis.

Keywords: social identity, social self, social knowledge, institutionalization, phenomenological sociology, methodological approach. 